\title{
ANALISIS RASIO KEUANGAN PT. TELEKOMUNIKASI INDONESIA TBK TAHUN 2017-2019
}

\author{
Felia Eka Srilestari ${ }^{1}$, Galuh Cahya Gumilang ${ }^{2}$, Hasbiyalloh ${ }^{3}$, Hendi Valerian ${ }^{4}$, \\ Husna Qurrota Aini ${ }^{5}$, Ikhwan Muliana Sanjaya ${ }^{6}$, Yayang Ikhyaul Maarif ${ }^{7}$, \\ Kadar Nurjaman ${ }^{8}$ \\ 1,2,3,4,5,6,7,8 Universitas Islam Negeri Sunan Gunung Djati Bandung \\ Email:feliaeka8@gmail.com
}

\begin{abstract}
Abstrak
Penelitian ini dilakukan untuk menganalisis rasio keuangan PT. Telekomunikasi Indonesia Tbk. selama periode 2017 hingga 2019 untuk melihat kemampuan perusahaan menggunakan rasio keuangan dan laporan perusahaan. Penelitian ini menggunakan data sekunder dengan memanfaatkan laporan keuangan dan laporan perusahaan. Alat analisis yang digunakan dalam penelitian ini adalah menggunakan rasio likuditas, rasio solvabilitas, rasio aktivitas, dan rasio profitabilitas. Berdasarkan hasil penelitian ini menunjukkan bahwa kinerja keuangan PT. Telekomunikasi Indonesia Tbk. selama periode penelitian mengalami peningkatan dan penurunan. Hasil Perhitungan rasio likuiditas yang terdiri dari Current Ratio, Quick Ratio, dan Cash Ratio untuk periode 2017 hingga 2019 menurun. Pengukuran dan rasio solvabilitas yang menggunakan Debt to Assets Ratio dan Debt to Equity Ratio untuk periode 2017 hingga 2019 meningkat. Untuk rasio aktivitas yang terdiri dari Total Asset Turn Over dan Fixed Asset TurnOver untuk periode 2017 hingga 2019 menurun. Dan untuk rasio profitabilitas yang terdiri dari Net Profit Margin, Return on Asset, Return on Equity 2017 hingga 2019 menurun.
\end{abstract}

Kata Kunci: Likuiditas, Solvabilitas, Aktivitas, Profitabilitas, Telkom.

\begin{abstract}
This research was conducted to analyze the financial ratios of PT. Telekomunikasi Indonesia Tbk. during the period 2017 to 2019 to see the company's ability to use financial ratios and company reports. This study uses secondary data by utilizing financial statements and company reports. The analytical tool used in this study is to use liquidity ratios, solvency ratios, activity ratios, and profitability ratios. Based on the results of this study indicate that the financial performance of PT. Telekomunikasi Indonesia Tbk. during the study period increased and decreased. The results of the calculation of liquidity ratios consisting of Current Ratio, Quick Ratio, and Cash Ratio for the 2017 to 2019 periods decreased. Measurement and solvency ratios using Debt to Assets Ratio and Debt to Equity Ratio for the period 2017 to 2019 increased. The activity ratio consisting of Total Asset Turn Over and Fixed Asset Turnover for the period 2017 to 2019 decreased. And for profitability ratios consisting of Net Profit Margin, Return on Assets, Return on Equity, 2017 to 2019 decreased.
\end{abstract}

Keywords: Liquidity, Solvency, Activity, Profitability,Telkom 


\section{A. PENDAHULUAN}

Pada dasarnya setiap perusahaan akan selalu berusaha agar perusahaannya tetap sehat, kinerja suatu perusahaan akan selalu diperhatikan oleh semua pihak dan demi menjaga kelangsungan hidup usaha, perusahaan akan berusaha untuk meningkatkan kinerjanya. Suatu perusahaan dikatakan baik apabila tujuan tercapai, salah satunya umtuk mendapatkan profit. Cara untuk melihat kinerja perusahaan bisa dilihat dari rasio keuangan perusahaan tersebut apakah posisi keuangannya seimbang atau tidak. Jika angka rasio lancar, maka perusahaan tersebut punya kemampuan yang baik dalam melunasi kewajibannya. Adapun penilaian kinerja perusahaan dapat menggunakan analisis rasio likuiditas, profitabilitas, solvabilitas, dan aktivitas

Rasio merupakan teknik analisis laporan keuangan yang paling sering digunakan dan merupakan instrumen yang dapat memberikan jalan keluar dan describe simpton suatu keadaan. Bila diartikan secara benar, rasio juga dapat address arcas yang memerlukan penelitian dan penanganan yang lebih mendalam.

Rasio keuangan adalah suatu indikator yang digunakan sebagai media analisa secara lebih mendalam terhadap sebab terjadinya suatu masalah. Menurut Van Horne dan Wachowizs (1997:133), rasio keuangan adalah "Indeks yang menghubungkan dua angka akuntansi dan diperoleh dengan membagi satu angka dengan angka lainnya". Dua angka akuntansi yang dimaksud disini yaitu sebagai contoh perhitungan hutang lancar dan aktiva lancar suatu perusahaan, dimana hasil dari perhitungan tersebut dinamakan rasio.

Analisis rasio dapat menyingkap kaitan dan sekaligus menjadi dasar komparasi yang menunjukkan kondisi atau kecenderungan yang tidak dapat dideteksi bila kita hanya melihat komponen-komponen itu sendiri. Adapun pengertian dari analisis rasio keuangan adalah analisis kuantitatif yang digunakan untuk mengevaluasi berbagai aspek kinerja operasi dan keuangan perusahaan berdasarkan informasi yang terdapat dalam laporan keuangan perusahaan seperti laporan neraca (balance sheet), laporan aliran kas (cash flow statement) dan laporan laba-rugi (income statement). Menurut Samryn (2011), analisis rasio keuangan adalah "suatu cara yang membuat perbandingan data keuangan 
perusahaan menjadi lebih arti. Rasio keuangan menjadi dasar untuk menjawab beberapa pertanyaan penting mengenai kesehatan keuangan dari perusahaan”.

Dalam perjalanan sejarahnya, Telkom telah melalui berbagai dinamika bisnis dan melewati beberapa fase perubahan, yakni kemunculan telepon, perubahan organisasi jawatan yang merupakan kelahiran Telkom, tumbuhnya teknologi seluler, berkembangnya era digital, ekspansi bisnis internasional, serta transformasi menjadi perusahaan telekomunikasi berbasis digital.

Perusahaan ini menyediakan berbagai layanan komunikasi lainnya termasuk interkoneksi jaringan telepon, multimedia, data dan layanan terkait komunikasi internet, sewa transponder satelit, sirkit langganan, televisi berbayar dan layanan VoIP. Perusahaan yang memiliki visi menjadi perusahaan yang unggul dalam penyelenggaraan Telecommunication, Information, Media, Edutainment dan Services ("TIMES") di kawasan regional ini telah mendominasi lebih dari 60 persen pangsa pasar broadband Indonesia. Artinya Telkom sudah memiliki lebih dari 19 juta pelanggan broadband. Telkom memiliki kapasitas gateway internet lebih dari 106,4 Gbps. Perusahaan ini selalu berusaha memastikan kecukupan gateway internet guna memenuhi kebutuhan konsumen baik dari fixed broadband maupun mobile Broadband.

Perhitungan rasio keuangan sangatlah penting untuk mengetahui aliran keuangan perusahaan setiap periodenya, untuk mengukur seberapa baik kinerja yang dilakukan oleh perusahaan tersebut termasuk PT. Telekomunikasi Indonesia Tbk yang merupakan Badan Usaha Milik Negara yang bergerak di bidang jasa layanan teknologi informasi dan komunikasi dan jaringan telekomunikasi di Indonesia. Pemegang saham mayoritas Telkom adalah Pemerintah Republik Indonesia sebesar $52.09 \%$, sedangkan $47.91 \%$ sisanya dikuasai oleh publik.

\section{B. METODE ANALISIS}

Metode pengumpulan data dilakukan dalam penelitian ini dengan dokumentasi untuk memperoleh informasi dengan cara melihat data-data yang terdapat dalam dokumentasi-dokumentasi tempat usaha yang diperoleh dari internet dan data laporan keuangan di BEI (www.idx.co.id) dan di 
www.telkom.co.id. Kemudian dengan menggunakan kepustakaan untuk memperoleh data skunder, seperti penelaahan buku-buku referensi, hasil-hasil penelitian terdahulu, maupun literatur lainnya yang berhubungan dengan penelitian yang dilakukan saat ini. Jangkauan penelitian ini dilakukan pada PT Telekomunikasi Indonesia Tbk, di Bursa Efek Indonesia (www.idx.co.id), dan dikhususkan pada masalah yang berhubungan dengan kinerja laporan keuangannya ditinjau dari rasio keuangan yang terdiri dari rasio likuiditas, rasio solvabilitas, rasio aktivitas, rasio profitabilitas, dan penilaian periode tahub 2017 sampai tahun 2019. Rincian data yang diprelukan untuk memperoleh gambaran yang jelas tentang masalah dan pemecahan serta mempermudah pembahasan, maka data-data yang diperlukan untuk melengkapi tujuan penulisan ini adalah kondisi atau gambaran umum PT Telekomunikasi Indonesia Tbk, struktur organisasi laporan keuangan yang berupa laporan laba rugi tahun 2017-2019, dan neraca per 31 desember tahun 2017-2019.

Alat analisis yang digunakan untuk mengukur laporan keuangan adalah sebagai berikut:

\section{Rasio Likuiditas}

Tabel 1. Standar industri rasio likuiditas

\begin{tabular}{lll}
\hline No & Jenis rasio & Standar Industri \\
\hline 1 & Rasio Lancar (Current Ratio) & 2 Kali \\
2 & Rasio Cepat (Quick Ratio) & $1,5 \mathrm{kali}$ \\
3 & Rasio Kas (Cash Ratio) & $50 \%$ \\
\hline
\end{tabular}

\section{Rasio Solvabilitas}

Tabel 2. Standar industri rasio solvabilitas

\begin{tabular}{lll}
\hline No & Jenis rasio & Standar Industri \\
\hline 1 & Debt to Assets Ratio (DAR) & $35 \%$ \\
2 & Debt to Rquity Ratio (DER) & $90 \%$ \\
\hline
\end{tabular}

\section{Rasio Aktivitas}


Tabel 3. Standar industri rasio aktivitas

\begin{tabular}{lll}
\hline No & Jenis rasio & Standar Industri \\
\hline 1 & Total Assets Turn Over (TATO) & 2 Kali \\
2 & Fixed Assets Turn Over (FATO) & 5 kali \\
\hline
\end{tabular}

\section{Rasio Profitabilitas}

Tabel 4. Standar industri rasio Profitabilitas

\begin{tabular}{lll}
\hline No & Jenis rasio & Standar Industri \\
\hline 1 & Net Profit Margin (NPM) & $20 \%$ \\
2 & Return on Assets (ROA) & $3 \%$ \\
3 & Return on Equity (ROE) & $40 \%$ \\
\hline
\end{tabular}

\section{HASIL PENELITIAN DAN PEMBAHASAN}

\section{Rasio Likuiditas}

Menurut (Handono Mardiyanto, 2009:54) Likuiditas adalah kemampuan perusahaan untuk membayar kewajiban jangka pendek (utang) tepat waktu, termasuk melunasi hutang jangka panjang yang jatuh tempo pada tahun yang bersangkutan. Jadi dapat diartikan bahwa rasio likuiditas merupakan rasio yang menunjukkan kemampuan suatu perusahaan untuk memenuhi kewajiban jangka pendek yang harus segera dipenuhi pada saat yang tepat.

Adapun analisis Laporan Keuangan pada PT. Telekomunikasi Indonesia, Tbk pada periode tahun 2017-2019 yang penulis ambil yaitu mengenai analisis Rasio Likuiditas yang terdiri dari : (1) current ratio (2) quick rasio, (3) cash ratio, dan (4) Cash TurnOver Ratio.

Adapun penjelasannya adalah sebagai berikut :

a. Current Rasio (Rasio Lancar)

Rasio Lancar atau Current Rasio digunakan untuk mengukur kemampuan perusahaan dalam menutup atau membayar kewajiban lancar dengan menggunakan aktiva lancarnya. Rasio lancar juga menunjukkan tingkat keamanan kreditor jangka pendek/ kemampuan perusahaan untuk membayar 
utang-utang tersebut. Semakin kecil utang lancar maka semakin besar persentase current rasio.

Dalam rasio lancar (Current Ratio). Semakin tinggi nilai rasionya maka perusahaan tersebut akan semakin likuid. Yang berarti kemampuan perusahaan dalam memenuhi kewajiban jangka pendeknya pun tinggi. Standar rasio industri untuk current ratio adalah $100 \%$ atau 1 kali. Ini berarti perusahaan tersebut tidak mengalami kesulitan dalam kemampuan memenuhi kewajiban jangka pendeknya.

Rumus untuk mencari Current Ratio yaitu:

$$
\text { Current Ratio }=\frac{\text { Aktiva Lancar }}{\text { Hutang Lancar }} \times 100 \%
$$

\section{b. Quick Rasio (Rasio Cepat)}

Rasio Cepat (Quick Ratio) merupakan sebuah pengukuran kemampuan perusahaan dalam memenuhi kewajiban jangka pendek dengan aktiva lancar tanpa memperhitungkan persediaan (inventory). Rasio cepat juga digunakan untuk mengukur kemampuan perusahaan dalam menutup atau membayar kewajiban lancar dengan menggunakan aktiva lancar tanpa memasukkan nilai persediaannya. Rasio Cepat (Quick Ratio) memiliki standar rasio industri yaitu $150 \%$ atau 1,5 kali. Jika suatu perusahaan memiliki nilai kurang dari 1,5 maka perusahaan itu dapat dikatakan bahwa perusahaan tersebut tidak dapat membayar kewajiban lancarnya tepat waktu.

Rumus untuk mencari Quick Ratio yaitu:

$$
\text { Quick Ratio }=\frac{\text { Aktiva Lancar }- \text { persediaan }}{\text { Hutang Lancar }} \times 100 \%
$$

\section{c. Cash Rasio (Rasio Kas)}

Rasio Kas (Cash Ratio) adalah sebuah rasio yang digunakan untuk mengukur seberapa banyak kas dan setara kas yang ada untuk mampu membayar kewajiban jangka pendek, atau dapat juga disebut sebuah rasio 
yang digunakan untuk membandingkan antara kas dan aktiva lancar setara kas dengan kewajiban lancar. Yang dimaksud dengan aktiva lancar setara kas adalah aktiva yang dapat dengan mudah dan segera diuangkan .

Rasio Kas yang terlalu tinggi menunjukkan penggunaan aset yang kurang maksimal bagi perusahaan. Standar rasio industri untuk cash ratio adalah $50 \%$. Rumus untuk mencari Cash Ratio yaitu:

$$
\text { Cash Ratio }=\frac{\text { Kas }+ \text { Setara Kas }}{\text { Hutang Lancar }} \times 100 \%
$$

\section{Rasio Solvabilitas}

Rasio solvabilitas (leverage) merupakan rasio yang digunakan untuk mengukur sejauh mana aktiva perusahaan dibiayai dari hutang. Artinya berapa besar beban utang yang ditanggung perusahaan dibandingkan dengan aktivanya. Dalam arti luas dikatakan bahwa rasio ini digunakan untuk mengukur kemampuan perusahaan untuk membayar seluruh kewajibannya, baik jangka pendek maupun jangka panjang apabila perusahaan dibubarkan (dilikuidasi).

Semakin tinggi rasio solvabilitas maka semakin tinggi pula risiko kerugian yang dihadapi, tetapi juga ada kesempatan mendapatkan laba yang besar. Sebaliknya apabila perusahaan memiliki rasio solvabilitas yang rendah tentu mempunyai risiko kerugian yang lebih kecil. Dampak ini juga mengakibatkan rendahnya tingkat hasil pengembalian (return) pada saat perekonomian tinggi.

Jenis-jenis rasio Solvabilitas yaitu:

\section{a. Debt to Assets Ratio (DAR)}

Debt to Assets Ratio merupakan rasio utang yang digunakan untuk mengukur perbandingan antara total hutang dengan total aktiva. Dengan kata lain, seberapa besar aktiva perusahaan dibiayai oleh hutang atau seberapa besar hutang perusahaan berpengaruh terhadap pengelolaan aktiva.

Nilai standar rasio industri untuk debt to assets ratio adalah $35 \%$, ini memiliki arti sebagian kecil aset perusahaan dibiayai melalui hutang. Jika 
rasionya lebih besar dari 35\%, berarti sebagian besar aset perusahaan dibiayai melalui hutang.

Rumus untuk mencari Debt to Assets Ratio (DAR) yaitu:

$$
\begin{gathered}
\text { DAR }=\frac{\text { Total Utang }(\text { Debt })}{\text { Total Aktiva }(\text { Assets })} \times 100 \% \\
\text { atau } \\
\text { DAR }=\frac{\text { Total Utang }(\text { Debt })}{\text { Total Aktiva }(\text { Assets })} \times 100 \%
\end{gathered}
$$

\section{b. Debt to Equity Ratio (DER)}

Debt to Equity Ratio (DER) merupakan rasio yang digunakan untuk menilai utang dengan ekuitas. Rasio ini dicari dengan cara membandingkan antara seluruh utang, termasuk utang lancar dengan seluruh ekuitas.

Debt to Equity Ratio (DER) mengukur modal yang dimiliki perusahaan untuk membayar hutang. Rasio ini memiliki nilai standar industri yaitu 1. Hal itu berarti bahwa jumlah modal sama untuk membayar utangnya. Jika lebih 1 maka modal yang dimiliki mayoritas dibayar oleh utang.

Rumus untuk mencari Debt to Equity Ratio (DER) yaitu:

$$
\mathrm{DAR}=\frac{\text { Total Utang }(\text { Debt })}{\text { Total Modal }(\text { Equity })} \times 100 \%
$$

\section{Rasio Aktivitas}

Rasio aktivitas adalah rasio yang digunakan untuk menilai efisiensi atau efektivitas perusahaan dalam pemanfaatan semua sumber daya atau aset (aktiva) yang dimiliki oleh suatu perusahaan. Dari hasil pengukuran ini, akan diketahui berbagai hal yang berkaitan dengan aktivitas perusahaan sehingga manajemen dapat mengukur kinerja mereka selama ini. Kemudian hasil ini dibandingkan dengan hasil pengukuran beberapa periode sebelumnya. 
Pada analisis ini untuk menentukan efisiensi dari PT. Telekomunikasi Indonesia Tbk. penguji hanya akan menggunakan dua perhitungan rasio saja, yaitu (1) Total Asset TurnOver (TATO), dan (2) Fixed Asset TurnOver (FATO). Karena dengan melakukan dua analisis ini sudah dapat memberikan jawaban mengenai efisiensi dari perusahaan.

\section{a. Total Asset Turn Over (TATO)}

Total Asset TurnOver (TATO) adalah sebuah analisis yang melakukan perbandingan antara hasil penjualan dengan rata-rata total aset suatu perusahaan. Semakin besar hasil yang didapatkan dari rasio ini maka kondisi operasional perusahaan semakin baik. Artinya perputaran aset lebih cepat dan perusahaan dianggap mampu untuk memanfaatkan setiap rupiah yang dimiliki untuk menghasilkan penjualan sehingga dapat menghasilkan laba yang semakin optimal.

Rumus untuk mencari Total Asset TurnOver (TATO) yaitu:

$$
\text { TATO }=\frac{\text { Penjualan Bersih }}{\text { Rata }- \text { rata Total Aset }} \times 100 \%
$$

atau

$$
\text { TATO }=\frac{\text { Penjualan }}{(\text { Total Aset awal tahun }+ \text { total aset akhir tahun }) / 2} \times 100 \%
$$

\section{b. Fixed Asset Turn Over (FATO)}

Rasio perputaran aset tetap atau fixed asset turnover (FATO) adalah perbandingan antara penjualan dengan aktiva tetap yang dimiliki suatu perusahaan. Rasio ini berfungsi untuk mengevaluasi kemampuan perusahaan dalam memanfaatkan asetnya secara efektif. Jika perputarannya cepat, maka perusahaan dianggap efektif dalam memanfaatkan asetnya. Dan jika lambat (rendah), maka kapasitas akan terlalu besar atau ketersediaan aktiva tetap banyak sehingga kurang bermanfaat.

Rumus untuk mencari Fixed Asset TurnOver (FATO) yaitu: 


$$
\text { FATO }=\frac{\text { Penjualan }}{\text { Total Aset Tetap }} \times 100 \%
$$

\section{Rasio Profitabilitas}

Rasio Profitabilitas (Profitability Ratio) adalah rasio atau perbandingan untuk mengetahui kemampuan perusahaan untuk mendapatkan laba (profit) dari pendapatan (earning) terkait penjualan, aset dan ekuitas berdasarkan dasar pengukuran tertentu. Jenis-jenis rasio profitabilitas dipakai untuk memperlihatkan seberapa besar laba atau keuntungan yang diperoleh dari kinerja suatu perusahaan yang memengaruhi catatan atas laporan keuangan yang harus sesuai dengan standar akuntansi keuangan.

Dalam analisis laporan keuangan pada PT. Telekomunikasi Indonesia Tbk. penguji akan menggunakan enam jenis rasio profitabilitas untuk mengetahui mengenai kemampuan perusahaan untuk mendapatkan laba.

Berikut adalah jenis-jenis rasio profitabilitas yang akan digunakan:

\section{a. Net Profit Margin (NPM)}

Net Profit Margin mengukur keberhasilan suatu perusahaan dengan menggunakan persentase laba bersih terhadap penjualan bersih suatu perusahaan. Nilai yang tinggi dari rasio ini menunjukkan bahwa perusahaan menetapkan harga produknya dengan benar dan berhasil mengendalikan biaya dengan baik.

Rumus untuk mencari Net Profit Margin (NPM) yaitu:

$$
\mathrm{NPM}=\frac{\text { Earning After Interest and Tax (EAIT) }}{\text { Pendapatan }} \times 100 \%
$$

\section{b. Return on Asset (ROA)}

Salah satu tujuan dari aset pada perusahaan adalah mendapatkan pendapatan atau laba. Return on Asset (ROA) berguna dalam mengukur efisiensi perusahaan dalam mengubah uang yang dibelanjakan pada aset 
menjadi laba bersih. Semakin tinggi nilai dari rasio ini maka akan semakin baik.

Rumus untuk mencari Return on Asset (ROA) yaitu:

$$
\mathrm{ROA}=\frac{\text { Earning After } \text { Interest and Tax (EAIT) }}{\text { Total Asset }} \times 100 \%
$$

c. Return on Equity (ROE)

Return on Equity (ROE) mengukur efisiensi sebuah perusahaan menggunakan modal yang dimiliki untuk menghasilkan keuntungan dan menumbuhkan perusahaannya. Semakin tinggi nilai dari rasio ini maka akan semakin baik.

Rumus untuk mencari Return on Equity (ROA) yaitu:

$$
\mathrm{ROE}=\frac{\text { Earning After Interest and Tax (EAIT) }}{\text { Equity }} \times 100 \%
$$

\section{HASIL PENELITIAN}

Hasil penelitian merupakan hasil analisis rasio keuangan PT. Telekomunikasi Indonesia Tbk. dengan menggunakan rumus-rumus rasio dan menggunakan metode analisis horizontal \& menggunakan pendekatan Time Series selama tiga periode waktu dari tahun 2017-2019.

\begin{tabular}{|c|c|c|c|c|c|}
\hline \multirow{2}{*}{ No } & \multirow{2}{*}{ Keterangan } & \multirow{2}{*}{ Standar Industri } & \multicolumn{3}{|c|}{ Tahun } \\
\hline & & & 2017 & 2018 & 2019 \\
\hline 1 & Rasio Likuiditas & & & & \\
\hline & Current ratio & 1 kali & 1,05 kali & 0,9 kali & 0,7 kali \\
\hline & Hasil & & I iloid & Tidak & Tidak \\
\hline & & & & Likuid & Likuid \\
\hline & Quick ratio & 1,5 kali & 1,03 kali & 0,9 kali & 0,7 kali \\
\hline & Hasil & & Likuid & Tidak & Tidak \\
\hline
\end{tabular}

Tabel 5. Hasil Perhitungan Rasio 
ARTIKEL

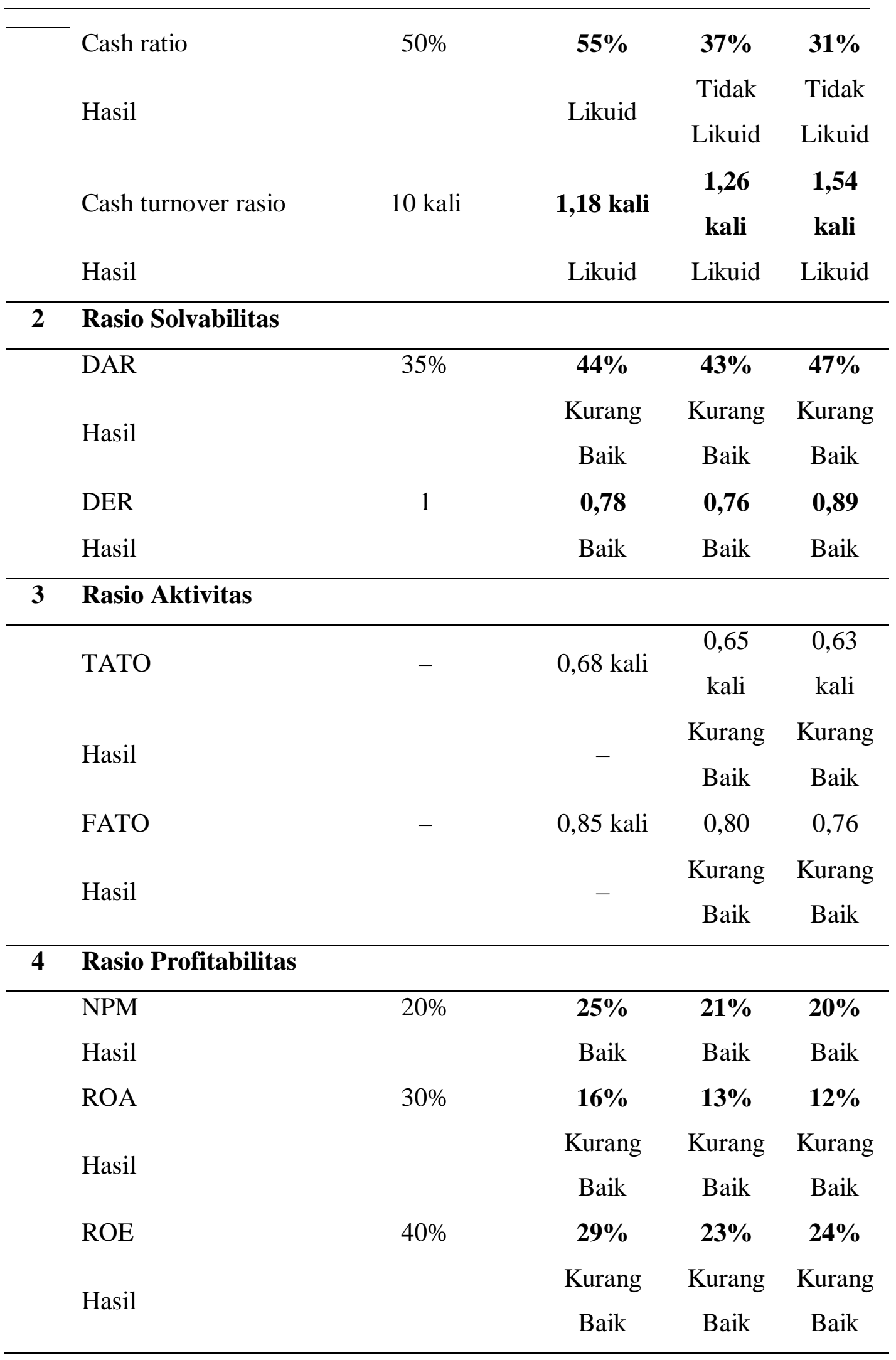

\section{PEMBAHASAN}

1. Rasio Likuiditas 
Berdasarkan hasil analisis Current Ratio (CR) atau rasio lancar pada PT. Telkom pada tahun 2017 diperoleh nilai CR sebesar 105\% yang berarti PT. Telkom dalam kondisi yang likuid karena berada di atas standar tingkat likuiditas industri, tetapi hal ini berbeda dengan 2 tahun selanjutnya Pada tahun 2018 diperoleh nilai CR-nya sebesar 93\%, dan tahun 2019 diperoleh nilai CR-nya sebesar $71 \%$. Hal tersebut menandakan tingkat likuiditas Telkom dalam kondisi tidak baik karena berada di bawah batas standar yaitu sebesar $100 \%$.

Dari hasil analisis Quick Ratio PT. Telkom tahun 2017 diperoleh rasio cepat sebesar 103\%. Pada tahun 2018 diperoleh rasio cepat sebesar 93\% dan di tahun 2019 diperoleh rasio cepat sebesar 70\%. Hal ini mengartikan Telkom kurang bisa untuk membayar utang lancarnya dengan aset yang dimilikinya. Karena batas nilai rasio cepat yaitu $150 \%$ sedangkan Telkom memiliki nilai jauh di bawahnya. Semakin tinggi rasio cepat maka semakin baik hal ini disebabkan oleh aset lancar dikurangi persediaan lebih besar daripada utang lancar.

Hasil analisis Cash Ratio PT. Telkom tahun 2017 diperoleh rasio kas sebesar 55\%. Nilai ini mengartikan bahwa telkom memiliki cadangan kas dan setara kas yang lebih dari cukup untuk membayar utangnya. Tetapi rasio kas di Telkom mengalami penurunan pada 2 tahun berikutnya. Di tahun 2018 diperoleh rasio kas sebesar 37\% dan tahun 2019 diperoleh rasio kas sebesar 31\%. Nilai Rasio kas tersebut dikatakan kurang baik karena mengalami penurunan dan berada di batas bawah standar nilai rasio kas yaitu $50 \%$. Semakin tinggi rasio kas maka semakin baik hal ini disebabkan oleh kas dan setara kas lebih besar daripada utang lancar.

Jadi hasil analisis rasio likuiditas pada PT. Telkom mengalami fluktuasi. Pada tahun 2017 sempat mengalami keadaan yang baik dalam artian likuid, tetapi ditahun-tahun selanjutnya mengalami penurunan. Walaupun mengalami penurunan, tetapi Telkom cukup mampu untuk meningkatkan perputaran kasnya dari tahun 2017-2019.

\section{Rasio Solvabilitas}


Berdasarkan hasil analisis DAR pada PT. Telkom di tahun 2017 menunjukkan nilai DAR sebesar $44 \%$. Hal tersebut mengartikan bahwa $44 \%$ aset yang dimiliki Telkom dibayar melalui utang. Nilai ini menunjukkan nilai yang kurang baik karena batas standarnya adalah 35\% dan semakin kecil nilainya maka semakin baik. Di tahun 2018 Telkom mengalami peningkatan dengan memiliki nilai DAR sebesar 43\%. Sedangkan tahun berikutnya mengalami penurunan dengan memiliki nilai DAR yang naik dengan nilai $47 \%$.

Dari hasil analisis DER pada PT. Telkom di tahun 2017 diperoleh nilai DER sebesar 77\%. Tahun berikutnya 2018 mengalami penurunan nilai DER 1\% sehingga nilainya sebesar 76\%. Sedangkan pada tahun 2019 nilai DER sebesar 89\%. Nilai-nilai tersebut mengartikan bahwa kemampuan perusahaan untuk membayar utang jangka panjang dengan modalnya. Nilai DER PT. Telkom dikatakan cukup baik karena di bawah $100 \%$ yang menandakan mampu untuk membayar utangnya dengan modal yang dimiliki. Semakin tinggi rasio ini akan menunjukkan kinerja yang buruk bagi perusahaan.

Jadi berdasarkan analisis rasio solvabilitas yang telah dilakukan dapat ditemukan bahwa selama tahun 2017-2019 Telkom masih memiliki sebagian aset yang dibiayai oleh utang. Tetapi dalam ekuitasnya, Telkom mampu untuk mengatasi utangnya dengan modal yang dimilikinya selama periode waktu 2017-2019.

\section{Rasio Aktivitas}

Berdasarkan hasil analisis dari TATO tersebut di PT. Telkom pada tahun 2017 menunjukkan angka 68\%, pada tahun 2018 menunjukkan angka 65\%, dan pada tahun 2019 menunjukkan angka 63\%. Dalam hasil perhitungan TATO tidak ada standar acuan bakunya, maka untuk mengetahui nilainya baik atau buruk maka harus dibandingkan dengan tahun-tahun berikutnya atau sebelumnya. Dan hasil perbandingannya dari tahun 2017 ke tahun 2019 selalu mengalami penurunan. Artinya selama periode tersebut Perusahaan Telkom mengalami penurunan efisiensi dari penggunaan aset yang digunakan untuk penjualan. 
Dari hasil dari analisis tersebut menunjukkan FATO pada tahun 2017 di PT Telkom adalah 85\%, sedangkan pada tahun 2018 adalah 80\%, dan pada tahun 2019 hasilnya yaitu 76\%. Nilai dari angka tersebut harus dibandingkan seperti TATO untuk mengetahui apa nilainya baik atau buruk. Dan berdasarkan perbandingan FATO di PT. Telkom pada tahun 2017 lebih baik daripada tahun-tahun berikutnya. Tetapi meskipun pada tahun-tahun berikutnya terjadi penurunan, Telkom tetap mampu untuk melakukan perputaran aset tetapnya lebih dari separuhnya untuk menghasilkan penjualan.

Jadi hasil analisis rasio aktivitas pada PT. Telkom selama periode 20172019 menunjukkan bahwa telkom kurang efisien dalam memanfaatkan asetnya karena selalu mengalami penurunan di tiap tahunnya. Tetapi walaupun tiap tahun nilainya selalu turun, Telkom tetap bisa memanfaatkan dan memutarkan lebih dari separuh aset yang dimilikinya menjadi penjualan dan menghasilkan laba.

\section{Rasio Profitbilitas}

Dari hasil analisis rasio profitabilitas pada rasio Net Profit Margin (NPM) PT Telekomunikasi Indonesia Tbk pada tahun 2017 sampai tahun 2019 terlihat selalu mengalami penurunan. di mana pada tahun 2017 NPM-nya sebesar 25\%, pada tahun 2018 sebesar 21\% dan pada tahun 2019 sebesar $20 \%$. Walaupun pendapatan selalu meningkat dari tahun ke tahunnya, tetapi laba bersih dari tahun 2017 sampai tahun 2019 mengalami penurunan. Tetapi walaupun hasilnya selalu mengalami penurunan, nilai NPM-nya masih berada dalam batas standar industri pesaing-pesaingnya.

Dalam analisis rasio ROA pada PT Telkom di tahun 2017 sampai tahun 2019 selalu mengalami penurunan walaupun tidak signifikan. Pada tahun 2017 ROA nya sebesar 16\%, pada tahun 2018 sebesar 13\%, dan pada tahun 2019 sebesar $12 \%$. Selain nilainya menunjukkan penurunan, nilainya juga berada jauh di bawah dari standar industri yaitu sebesar 30\%. Hal ini menunjukkan bahwa aktiva atau aset PT Telkom tidak dapat cepat berputar dengan baik dan meraih laba yang besar. 
Untuk analisis ROE pada PT Telkom di tahun 2017 sampai tahun 2019 tidak stabil. Di mana pada tahun 2017 ROE nya sebesar 29\%, sedangkan pada tahun 2018 mengalami penurunan yang lumayan cukup signifikan menjadi 23\%, dan pada tahun 2019 mengalami peningkatan walaupun hanya naik $1 \%$. Nilai ROE pada PT. Telkom berada di bawah standar industri, tetapi ekuitas pada tahun 2017 sampai tahun 2019 selalu meningkat walaupun tidak diiringi dengan meningkatnya laba dikarenakan masih ada biaya-biaya yang terpakai juga. Hal ini yang menyebabkan ROE setiap tahunnya kecil dan menurun,

Jadi hasil analisis rasio profitabilitas pada PT. Telkom menunjukkan bahwa profitabilitas dalam PT. Telkom mengalami fluktuasi. Pada tahun 2017 dan 2018 mengalami penurunan yang menyebabkan penurunan juga dalam laba bersih yang diterimanya. Hal ini dapat disebabkan oleh banyak faktor, salah satu faktor yaitu karena Telkom tidak bisa memanfaatkan asetnya dengan optimal untuk memutar laba. Tetapi walaupun 2017-2018 mengalami penurunan, di tahun selanjutnya 2019 Telkom berhasil mengatasi penurunan laba tersebut yang ditandai dengan naiknya pendapatan, walaupun tidak meningkatkan laba bersih yang signifikan.

\section{E. KESIMPULAN}

Berdasarkan pehitungan dan pembahasan dari hasl analisis laporan keuangan PT.Telekomunikasi Indonesia Tbk. Selama 3 tahun terakhir yang teah dibahas sebelumya peneliti menarik kesimpulan bahwa PT.Telekomunikasi Indonesia Tbk. Adalah perusahaan Badan Usaha Milik Negara (BUMN) yang bergerak di bidang jasa layanan teknologi informasi dan komunikasi (TIK) dan jaringan telekomunikasi di Indonesia. Perusahaan ini diperdagangnkan di BEI dan NYSE dengan kode "TLKM" dan "TLK"

Dalam rasio likuiditas dengan menggunakan alat analisis current ratio, quick ratio, cash raio dan cash turn over ratio dari tahun 2017-2019 menunjukan bahwa perusahaan dalam keadaan tidak likuid, kecuali untuk tahun 2017 dan cash turn over ratio yang semuanya likuid. Dalam rasio solvabilitas di tahun 2017-2019 terjadi perbedaan antar rasio yang diproyeksikan dengan Debt to Asset Ratio dan Debt to Equity Ratio. Untuk DAR semuanya berada dalam kondisi kurang baik, sedangkan DER menunjukan semuanya dalam kondisi baik. Kemudian, untuk 
rasio aktivitas yang diproyeksikan dengan Total Asset Turn Over dan Fixed Asset Turn Over menunjukan bahwa perusahaan ini berada dalam kondisi kurang baik.

Dalam Rasio Profitabilitas yang diproyeksikan dengan NPM, ROA, dan ROE sebagai alat analisis menunjukan bawa PT.Telekomunikasi Indonesia Tbk di tahun 2017-2019 berada dalam kondisi kurang baik, kecuali untuk rasio NPM yang semuanya baik di tahun 2019.

Tingkat rasio dari likuiditas, solvabilitas, aktivitas dan profitabilitas, menunjukan bahwa perusahaan berada dalam kondisi kurang baik secara mayoritas.

\section{DAFTAR PUSTAKA}

Fahmi, I. (2011). Analisis Laporan Akuntansi. Bandung: Alfabeta

Fahmi, Irham. (2013). Pengantar Manajemen Keuangan. Bandung: Alfabeta

Harahap, Sofyan Syafri. (2015). Analisis Kritis atas Laporan Keuangan. Edisi 110. Jakarta: Rajawali Pers

Kariyato. (2017). Analisis Laporan Keuangan. Malang: Univesitas Brawijaya Press (UB Press)

Kasmir. (2012). Analisis Laporan Keuangan. Jakarta: PT.Rajagrafindo Persada

Martono dan Harjito, D, Agus. (2005). Manajemen Keuangan. Yogyakarta: Ekonisia.

Prihadi, T. (2019). Analisis Laporan Keuangan - Konsep dan Aplikasi. Jakarta: PT Gramedia Pustaka Utama

https://www.telkom.co.id

IDX. (t.thn.). Profil Perusahaan Telkom. dari IDX: Dipetik 24 Juni 2020

https://www.idx.co.id/perusahaan-tercatat/profil-perusahaan-

tercatat/detail- profile-perusahaan-tercatat/?kodeEmiten=TLKM

www.idx.co.id 